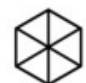 \\ LEUPHANA \\ UNIVERSITÄT LÜNEBURG
}

\section{Establishment exits in Germany}

Fackler, Daniel ; Schnabel, Claus; Wagner, Joachim

Publication date:

2012

Document Version

Publisher's PDF, also known as Version of record

Link to publication

Citation for pulished version (APA):

Fackler, D., Schnabel, C., \& Wagner, J. (2012). Establishment exits in Germany: the role of size and age.

(Working Paper Series in Economics; No. 231). Institut für Volkswirtschaftslehre der Universität Lüneburg.

\section{General rights}

Copyright and moral rights for the publications made accessible in the public portal are retained by the authors and/or other copyright owners and it is a condition of accessing publications that users recognise and abide by the legal requirements associated with these rights.

- Users may download and print one copy of any publication from the public portal for the purpose of private study or research.

- You may not further distribute the material or use it for any profit-making activity or commercial gain

- You may freely distribute the URL identifying the publication in the public portal ?

Take down policy

If you believe that this document breaches copyright please contact us providing details, and we will remove access to the work immediately and investigate your claim. 


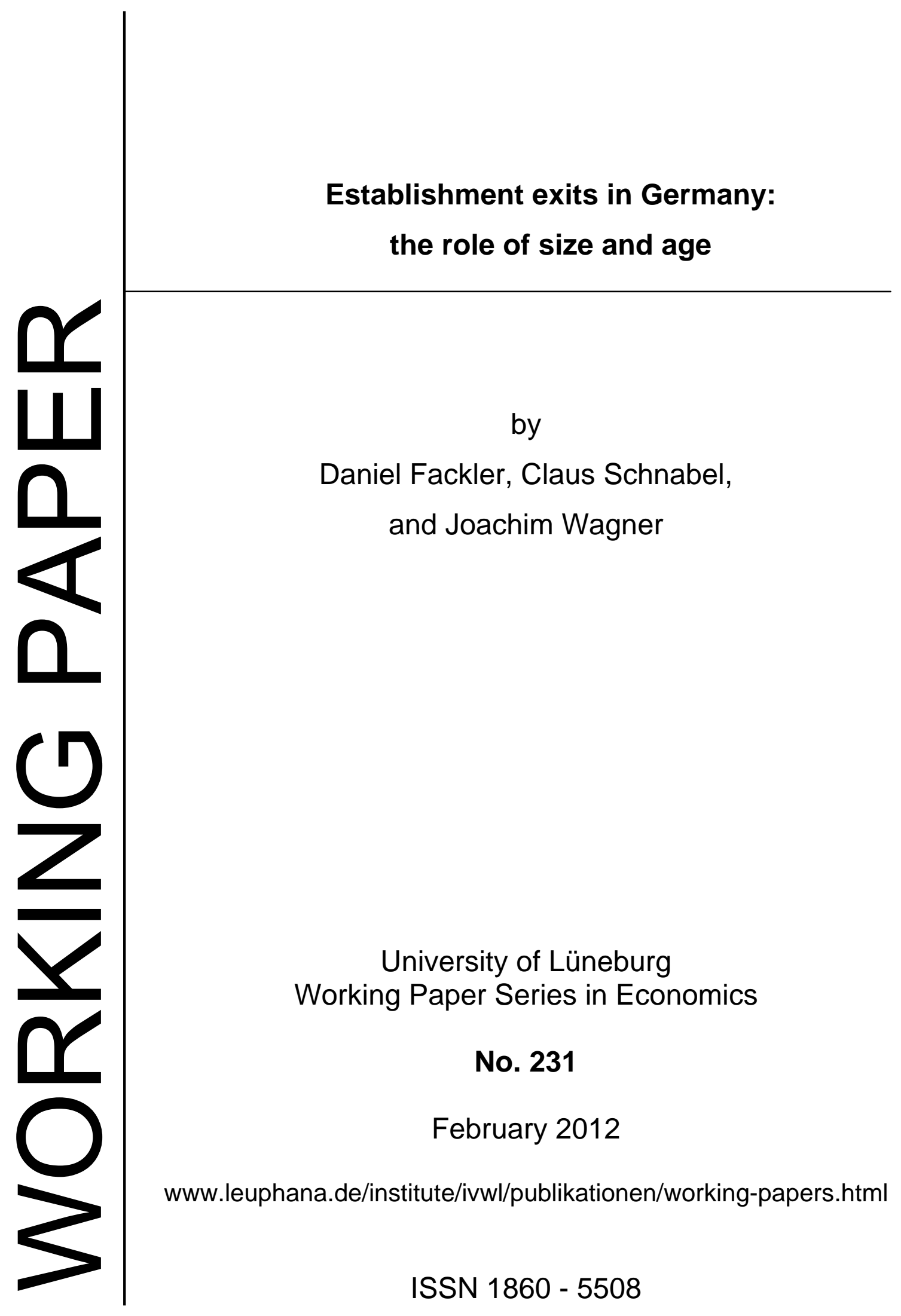




\title{
Establishment exits in Germany: the role of size and age*
}

\author{
Daniel Fackler ${ }^{\text {a }}$ \\ University of Erlangen-Nürnberg \\ Claus Schnabel ${ }^{b}$ \\ University of Erlangen-Nürnberg, IZA, LASER \\ Joachim Wagner ${ }^{c}$ \\ Leuphana University Lüneburg, IZA
}

\begin{abstract}
:
Using comprehensive data for West Germany, this paper investigates the determinants of establishment exit. We find that between 1975 and 2006 the average exit rate has risen considerably. In order to test various "liabilities" of establishment survival identified in the literature, we analyze the impact of establishment size and put a special focus on differences between young and mature establishments. Our empirical analysis shows that the mortality risk falls with establishment size, which confirms the liability of smallness. The probability of exit is substantially higher for young establishments which are not more than five years old, thus confirming the liability of newness. There also exists a liability of aging since exit rates first decline over time, reaching a minimum at ages 15 to 18 , and then rise again somewhat. The determinants of exit differ substantially between young and mature establishments, suggesting that young establishments are more vulnerable in a number of ways.
\end{abstract}

Keywords: firm exits, Germany

JEL classification: L2

\footnotetext{
* We would like to thank the German Research Foundation for financial support under the project SCHN 730/5-1 resp. WA 610/5-1 "Firm exit" (Betriebsschließungen) and the team of the Research Data Centre of the Federal Employment Agency at the Institute for Employment Research for their exceptional support and cooperation.

${ }^{a}$ University of Erlangen-Nürnberg, Chair of Labour and Regional Economics, Lange Gasse 20, 90403 Nürnberg, Germany, E-mail: daniel.fackler@wiso.uni-erlangen.de

${ }^{b}$ University of Erlangen-Nürnberg, Chair of Labour and Regional Economics, Lange Gasse 20, 90403 Nürnberg, Germany, E-mail: claus.schnabel@wiso.uni-erlangen.de

${ }^{c}$ Leuphana University Lüneburg, Institute of Economics, P.O. Box 2440, 21314 Lüneburg, Germany,

E-mail: Wagner@leuphana.de
} 


\section{Introduction}

In a market economy, entries and exits of firms or establishments are important vehicles of structural change and economic development. Since they may affect, inter alia, the pace of innovation and change and the level of (un)employment in a society, entries and exits have increasingly received attention by economic policy and by academic researchers. The majority of studies published focus on entries, and here in particular on the success of newly founded firms over the years in terms of survival rates, employment growth, and other indicators of firm performance (for surveys of stylized facts, see Geroski 1995 or Caves 1998). What is equally important but has been the subject of much less research, however, is the exit behavior of establishments, which affects both the employees losing their jobs and the structure of the economy as a whole.

To be sure, there exists a substantial empirical literature on exits and their determinants in several countries (see, e.g., Bernard/Jensen 2007 for the US, Box 2008 for Sweden, Bellone et al. 2008 for France, Disney et al. 2003 for the UK, Esteve-Pérez/Manez-Castillejo 2008 for Spain). Recent studies for Germany include, inter alia, Harhoff et al. (1998), Addison et al. (2004), Niese (2003), and Wagner (1999, 2010). However, although this (national and international) research has produced some interesting findings, we cannot really speak of a large number of stylized facts yet. These findings include that the size and age of establishments seem to play a role for exits (although the detailed age nexus is still disputed, see e.g. Hannan et al. 1998), that the determinants of exits seem to differ between older and younger firms (see Bellone et al. 2008, Jensen et al. 2008), and that the exit probability of younger firms is probably more susceptible to variations in economic conditions (see Jensen et al. 2008). Not all of these findings could be tested and confirmed yet for Germany. In addition, a certain limitation of existing German studies is that some of these focus on single federal states, analyze specific sectors only (in particular manufacturing), or cover only short time periods.

Against this backdrop, our paper contributes to the literature in four ways: First, by using a representative sample of 50 percent of all establishments in 1975-2006, we are able to chart establishment exits in (West) Germany in much more detail than previously possible, and this for a period of more than 30 years. Second, our rich 
data set allows us to investigate the role of internal determinants (such as establishment size and age) as well as of external factors affecting establishment mortality (such as the regional economic situation and the business cycle). Third, and more specifically, we are able to test various "liabilities" firms are confronted with when attempting to prosper and survive that have been identified in the extant literature, such as the liabilities of smallness, of newness, and of aging. Finally, as extant knowledge on exits mainly refers to newly founded firms, we investigate whether the determinants of exit differ between young and older establishments, a question that (to the best of our knowledge) has not been investigated yet for Germany.

\section{Data and identification of exits}

For the following analysis we use a large and representative administrative dataset namely the Establishment History Panel (BHP) provided by the Research Data Centre of the Federal Employment Agency at the Institute for Employment Research. The BHP contains a random sample of 50 percent of all establishments with at least one employee liable to social security and currently covers the period 1975 to 2008 . The data are annual and reflect the situation in the establishment on June 30th of each year. It is created by aggregating the underlying social security data - the "Employee and Benefit Recipient History" (BLH) - on establishment level. The BHP contains information on industry ${ }^{1}$, location, number of employees, structure of the workforce and the wage structure (for more detailed information see Spengler 2008, Hethey-Meier/Seth 2010). As the BHP covers all industries (not just manufacturing) and a longer time span than other datasets, it enables us to provide comprehensive evidence on establishment exits. That said, a certain limitation of our dataset is the lack of data on further potential determinants of exits reported in the literature such as the legal form of the company and productivity. We partly capture the influence of these missing variables by controlling for industry affiliation and establishment size.

Since every establishment is allocated a unique identification number which normally does not change, we are able to follow establishments over time. Generally we

\footnotetext{
${ }^{1}$ Since there are breaks in the industry classification, a time-consistent industry classification variable based on the procedure by Eberle et al. (2011) was provided by the Research Data Center.
} 
regard establishments as exits in that year when they appear in the data for the last time, that is when for the last time they report having employees who are liable to social security. Thus perforated establishment histories (e.g. if an establishment does not have any employees except the owner for some time) are not problematic for the largest part of the observation period but may become a problem at the current edge. In order to avoid that establishments are falsely regarded as exits at the current edge but reappear in the next year(s), we count them as exits only if they do not reappear in the data in the following two years. This procedure restricts our period of observation to 2006 .

Establishments are considered to be entries in the year when they first appear in the data. Hence for those establishments entering the dataset in 1976 or later we are able to calculate their exact age. For establishments that already appear in the data in 1975 we do not know whether they entered in 1975 or earlier, but if they still appear in the data, say, in 1981 we can definitely state that they are older than 5 years. $^{2}$

Identifying entries and exits only based on newly appearing or disappearing establishment numbers has an important shortcoming: events like a change of ownership or legal form, outsourcing or other administrative changes can result in a change of the establishment number, which would lead to an overestimation of the number of entries and exits ${ }^{3}$. To solve this problem, we use extension files on establishment histories provided by the Research Data Center that are based on the work by Hethey/Schmieder (2010) who analyzed worker flows between establishment numbers in the underlying personal level data. ${ }^{4}$ They use maximum clustered in- and outflows, that is the largest groups of workers switching from one establishment number to another, to classify newly appearing and disappearing establishment numbers into seven categories each. This procedure enables

\footnotetext{
${ }^{2}$ Because establishments do not appear in the data until they employ their first employee liable to social security, entry could also have occurred earlier than recorded in the data. Correspondingly, exit in our data set is equivalent to an establishment not having any employees anymore, but the actual death of the establishment in company registers can occur later.

${ }^{3}$ For a more detailed description of the problems concerning the identification of entries and exits see Brixy/Fritsch (2002).

${ }^{4}$ Since 1999 marginal part-time workers are also included in the BLH. For time-consistency those employment relationships were dropped in the analysis of Hethey/Schmieder (2010). For the identification of entries and exits we follow their approach.
} 
researchers to discriminate between true entries and exits and other events causing a change of the establishment number.

For very small establishments (with 1-3 employees), it would not be very meaningful to calculate the maximum clustered outflow relative to employment and it is therefore not possible to distinguish between true and spurious exits. Thus the number of exits in this size class is potentially overestimated. If a vanishing establishment has more than three employees and the maximum clustered outflow is less than 30 percent relative to employment, this is very likely to be a true exit and labeled "atomized death". Vanishing establishment numbers with a maximum clustered outflow between 30 and 80 percent relative to employment are labeled "chunky deaths". (An exception are establishments with a maximum clustered outflow relative to employment which is smaller than 80 percent and accounts for more than 80 percent of a newly appearing establishment's employment. These cases are labeled "spin-offs".) Even if vanishing establishments with a maximum clustered outflow between 30 and 80 percent do not completely cease to exist, this event reflects such a major restructuring that one cannot really speak of the same establishment. If the maximum clustered outflow is greater than 80 percent, it is likely that the establishment does not cease to exist. Depending on whether the successor (the establishment number where the maximum clustered outflow is employed in the next year) is a new or an existing establishment, these disappearing establishment numbers are regarded as "ID changes" or "takeovers", respectively. Those cases where a meaningful interpretation is not possible are labeled "unclear". The procedure which is applied to distinguish between true and spurious entries is generally similar to the one applied to exits (see Hethey/Schmieder 2010 for a more detailed description).

For our analysis we consider exits falling in one of the four categories small deaths (vanishing establishment numbers with 1-3 employees), atomized deaths, chunky deaths and spin-offs to be true exits. In contrast, ID changes and takeovers are rightcensored and are thus not regarded as exits (these make up about 2 percent of all exits in our sample), and disappearing establishment numbers that are labeled "unclear" by Hethey/Schmieder (2010) are excluded from our analysis (which is the case for 0.8 percent of exits). When the age of an establishment is taken into account, we also exclude establishments which enter the dataset during the period of 
observation but cannot be considered as true entries with certainty, namely spin-offs, ID changes and entries labeled "unclear". 5

We restrict our sample to the West German private sector, i.e. the public sector and other non-profit sectors are excluded from the analysis. East Germany is excluded because here reliable data are only available from 1993, and with this shorter period of observation it is not possible to conduct the same analyses as for West Germany.

Annual exit rates from 1975 to 2006 are presented in Figure 1. It can be seen that the average exit rate has risen over time by more than three percentage points. While in 1975 just 5.63 percent of establishments with employees liable to social security ceased to exist, in 2006 this was the case for 8.95 percent of establishments. In order to get a rough impression of how the exit rate varies with the business cycle, Figure 1 also depicts the unemployment rate in West Germany. Although both rates exhibit a positive correlation (their correlation coefficient is 0.69 ), strong cyclical movements in the exit rate cannot be observed. It is, however, interesting that the exit rate is highest in 2002, a year that falls in the economic downturn from 2001 to 2003.

(Figure 1 about here)

Figure 2 shows exit rates for different sectors averaged over the whole period of observation. As in other studies, it can be seen that exit rates are generally higher in the tertiary sector than in the secondary sector, which is likely due to higher entry and exit barriers in the secondary sector (see e.g. Woywode 1998: 129 f.). The results for the agriculture and the mining sector should be interpreted with care because exits in these sectors are strongly subject to political influence (e.g., subsidization, EU downsizing plans). In the following, we therefore exclude these two sectors from our analysis.

(Figure 2 about here)

\footnotetext{
${ }^{5}$ To verify the robustness of our results, we also applied other classifications of entries and exits, but this did not change our main insights.
} 


\section{Theoretical background and descriptive evidence}

The main theoretical contributions on firm exits come from two streams of literature, namely organizational ecology (see e.g. Baum/Amburgey 2005 for a survey) and industrial economics. Contributions from industrial economics are in particular learning models in the tradition of Jovanovic (1982) and approaches emphasizing the role of market structures (see e.g. Carlton/Perloff 2005 for a textbook treatment). There is also a lot of empirical literature on firm exits which, however, often focuses on the survival of new firms (Geroski 1995 and Caves 1998 provide surveys of the literature). This theoretical and empirical literature has identified various "liabilities" firms are confronted with when attempting to prosper and survive, which will be discussed in the following.

One of the most important factors affecting the mortality risk of firms is their size. The liability of smallness (Aldrich/Auster 1986) states that small firms or establishments are more likely to exit than their larger counterparts. Potential reasons for this relationship are that small firms are more likely to face financial constraints (Carreira/Silva 2010) or difficulties in finding qualified workers (Aldrich/Auster 1986). Small firms also operate on a smaller scale and therefore face cost disadvantages compared to larger firms (e.g. Audretsch/Mahmood 1994). Larger firms may further have better options to spread risks across various economic activities which should reduce their mortality risk (Geroski et al. 2010). Furthermore firm size may serve as a proxy for managerial talent, i.e. more skilled managers lead larger firms (Lucas 1978, Mata 1996).

The liability of smallness can be regarded as a stylized fact (Geroski 1995, Audretsch 1995: 149) found in many empirical studies (e.g. Dunne et al. 1989, EstevePerez/Manez-Castillejo 2008, Geroski et al. 2010). However, there are also studies that cannot clearly confirm this hypothesis (e.g. Audretsch et al. 1999). For Germany, Strotmann (2007), Wagner (1999) and Addison et al. (2004), inter alia, obtain evidence for the liability of smallness, whereas Wagner (1994) cannot detect a clear connection between start-up size and the probability of survival. Harhoff et al. (1998) differentiate between voluntary and involuntary liquidations (which is not possible in our data set) and find that the impact of size on the probability of exit is negative for voluntary liquidations and non-monotonic for involuntary liquidations. 
While studies on the survival of new entrants often focus on initial size (e.g. Strotmann 2007, Audretsch/Mahmood 1994), other studies concentrate on the current size of establishments (e.g. Esteve-Perez/Manez-Castillejo 2008). Generally the liability of smallness seems to hold for both initial and current size, but Mata et al. (1995) conclude that current size is a better predictor for exit than start-up size. Barron et al. (1994) state that it is crucial to control for age varying size when the age dependence of firms' mortality risk is investigated because older organizations tend to be larger and the mortality risk tends to decline with size. In our analysis we therefore use current establishment size (in addition, information on start-up size would only be available for those establishments founded in 1976 or later).

Figure 3 shows annual exit rates for different establishment size classes from 1975 to 2006. Descriptively the liability of smallness is clearly confirmed. By far the highest exit rates can be observed for establishments with 1-3 employees, but as we are not able to distinguish between true and spurious exits in this size class, this result should not be over-interpreted. As can be seen, the liability of smallness also holds for the other establishment size classes. Figure 3 shows that exit rates have increased for all size classes over time. This is most pronounced for establishments with 1-3 employees, where the exit rate in 2006 was about seven percentage points higher than in 1975. But also for establishments with more than 100 employees the exit rate has increased from 0.66 percent in 1975 to 1.09 percent in 2006.

\section{(Figure 3 about here)}

Another stylized fact often mentioned in the literature is that young firms face higher mortality risks than old firms (e.g. Geroski 1995, Audretsch 1995: 149, Caves 1998) which is usually referred to as the liability of newness. This hypothesis goes back to Stinchcombe (1965) who mentions several reasons why young organizations face disadvantages compared to older ones: for instance, new rules, routines and skills have to be evolved, which is costly and can induce efficiency losses. Additionally old organizations have advantages in terms of trust and social relations and more stable ties to customers or suppliers. A higher probability of exit for young establishments can also be derived from the passive learning model by Jovanovic (1982). When a firm enters the market, it does not know its true efficiency. As time goes by, firms 
obtain more accurate information about their efficiency. While efficient firms grow and survive, inefficient firms shrink and exit the market. ${ }^{6}$

That newness seems to be a liability is confirmed descriptively by Figure 4 which contrasts annual exit rates for young establishments (that are maximum five years old) and mature establishments (that are older than five years). It can be seen that the probability of exit is between six and nine percentage points higher for young establishments. Once again, it is visible that the exit rates have increased for both young and mature establishments.

(Figure 4 about here)

A closer look at the age dependence of firm exits shows that the relationship may be more complex. Whereas the liability of newness is often associated with a monotonic relationship between age and mortality risk, some authors argue that there is a nonmonotonic relationship. Brüderl/Schüssler (1990) and Fichman/Levinthal (1991) state that the probability of exit is initially low, increases up to a certain point and decreases afterwards which is referred to as the liability of adolescence. The argument is that newly founded organizations start with an initial stock of resources (financial resources, trust, goodwill etc.) which protects them from failure for an initial period. The greater the amount of these initial assets, the longer can this "honeymoon period" be expected to last.

As many studies do not take a non-monotonic relationship between age and the probability of exit into account, the liability of adolescence is not tested and observed very often. Additionally, even if a non-monotonic relationship between age and mortality risk is controlled for, a liability of adolescence cannot be detected if the "honeymoon period" is relatively short and data are based on yearly observations (as in our case). Brüderl/Schüssler (1990: 358) find that the hazard rate is highest after about six to nine months on average. Using data based on annual observations this would appear as a monotonic decline.

Both the liability of newness and the liability of adolescence assume that the mortality risk declines with age for the largest part of the organizational life span (Carrol/Hannan 2000: 289). In contrast to these hypotheses, the liability of aging

\footnotetext{
${ }^{6}$ Related models were developed, for instance, by Hopenhayn (1992) or Ericson and Pakes (1995). For a survey of this literature, see e.g. Woywode (1998: $61 \mathrm{ff}$.).
} 
states that the mortality risk can also increase with age (Aldrich/Auster 1986, Barron et al. 1994, Ranger-Moore 1997). The reason is that structural inertia tends to be more pronounced in older organizations. If inertial forces become too strong, this can cause an increasing mortality risk. By contrast, Hannan/Freeman (1984) argue that inertia also correlates positively with reliability and accountability, which favors older organizations and can therefore generate a liability of newness.

Barron et al. (1994) differentiate between two interpretations of the liability of aging. Strong inertial forces can constrain organizations' ability to respond to environmental changes and therefore increase the mortality risk of old organizations due to a changing environment. This is called the liability of obsolescence. Note that this is not a causal effect of aging since older organizations would not be disadvantaged in stable environments. In contrast the liability of senescence describes the causal effect of aging. If an organization has accumulated rules and routines to an extent that its efficiency is reduced, this can increase the mortality risk of older organizations even in stable environments.

The liability of newness if often confirmed empirically in studies not controlling for a non-monotonic relationship (see e.g. Carrol 1983, Freeman et al. 1983) while other studies find a liability of adolescence (e.g. Brüderl/Schüssler 1990, Fichman/Levinthal 1991) or a liability of aging (Barron et al. 1994, Ranger-Moore 1997). Surveying 18 studies on age dependence which control for age-varying size Hannan et al. (1998) do not find a clear picture. Five studies support the liability of newness in terms of monotonic declining mortality risks, four studies find an inverted U-shape confirming the liability of adolescence, and nine studies find positive age dependence supporting the liability of aging. ${ }^{7}$

For Germany it can be confirmed that young firms face higher mortality risks than older firms (see the survey by Wagner 2006). The studies by Brüderl/Schüssler (1990), Wagner (1994), Heckmann/Schnabel (2006) and Strotmann (2007) find evidence for a liability of adolescence. Some evidence for a liability of aging in West Germany is provided by Schindele/Weyh (2011) who use the BHP and analyze startup cohorts from 1976 to 2004. In accordance with the liability of newness they find

\footnotetext{
${ }^{7}$ For a more recent survey see Cafferata et al. (2009). A comparative analysis for ten OECD countries is provided by Bartelsman et al. (2005).
} 
that hazard rates are initially high, then decline steeply and stay relatively low. After about 18 years they start to increase again.

The theory on the age dependence of firm exits outlined above also suggests that the determinants of failure might differ between young and mature firms. Thornhill/Amit (2003) argue that while failures of young firms might be caused by a lack of resources and capabilities, failures of mature firms might occur due to high inertia and the inability to react to environmental changes. Also consistent with the liability of newness Bellone et al. (2008) state that young firms have to struggle to a greater extent with imperfect competition on product and factor markets and are therefore more vulnerable due to a lack of reputation, distribution channels or access to financial resources. In highly concentrated industries surviving is likely to be harder for newly founded firms while mature firms are protected by the industry structure (e.g. Geroski et al. 2010). Pointing to a "scarring effect of recessions", Ouyang (2009) argues that in economic downturns young firms which have less accurate information on their true productivity than mature firms may exit due to declining profitability although they are potentially highly productive.

There are very few studies addressing this issue empirically. Using a sample of 339 bankruptcies in Canada Thornhill/Amit (2003) find that failures of young firms are more often attributed to a lack of managerial skills while failures of older firms are more often attributed to environmental changes, which is consistent with the liability of newness and the liability of obsolescence. Bellone et al. (2008) estimate hazard functions separately for three age classes of French manufacturing firms. They find that the effects of firm performance (productivity, profitability) are stronger for mature firms and that the effects of market structures (concentration, turbulence) are stronger for young firms. Estimating hazard functions separately for new and incumbent firms in Australia, Jensen et al. (2008) observe that new firms are more vulnerable to economic conditions and industry competition. These results suggest that young firms are more strongly affected by imperfect competition.

The descriptive evidence presented in Figures 3 and 4 indicates that small and young firms indeed face higher mortality risks compared to larger and older firms. In the following section we will investigate whether these results also hold in a multivariate analysis. We will further examine whether the determinants of failure 
differ between young and mature establishments and what the age-dependence of establishment exits exactly looks like, i.e. whether the liabilities of adolescence and aging can be observed.

\section{Econometric analysis}

In this section we present the results of a multivariate analysis of the determinants of exit to analyze the "liabilities" outlined above more closely. Since our data are based on yearly observations, it seems appropriate to apply discrete time hazard models. According to Jenkins $(1995,2005)$, any standard model for binary dependent variables can be applied to estimate discrete time hazard models. As we want to analyze whether the determinants of exit differ between young and mature establishments, we estimate linear probability models to avoid problems with the interpretation of interaction terms (such as unclear signs or incorrect standard errors) that can occur in nonlinear models (Ai/Norton 2003), but do not arise in an OLS regression. Linear probability models are also well applicable to approximate the partial effects of explanatory variables in binary response models (see e.g. Wooldridge 2010: 562 f.). ${ }^{8}$

As explanatory variables we include establishment size to test the liability of smallness, using six dummy variables for size categories (described in detail in appendix table 1) to take account of potential non-linearities. To see whether young establishments face higher mortality risks, we use a dummy variable which is one if an establishment is maximum five years old, and zero otherwise. ${ }^{9}$ We further include five sectoral dummies as the probability of exit may also depend on industry structure (e.g. entry and exit barriers, technology). The survival chances of an establishment are also likely to depend on the structure of the workforce. In particular, one may assume that establishments with a better qualified workforce are more likely to

\footnotetext{
${ }^{8}$ As a robustness check, we also estimated those models without interaction terms by probit or complementary log-log (a discrete time proportional hazard model), which did not make a substantial difference.

${ }^{9}$ Classifying young establishments as maximum five years old might appear quite arbitrary, but it is in accordance with empirical evidence for Germany by Brixy et al. (2006) showing that differences in labor fluctuation, wages and working conditions between newly founded and incumbent firms narrow and vanish within the first five years as the newly founded firms mature. Moreover, the picture does not change if we classify young establishments as maximum four or six years old.
} 
survive. We therefore use the Blossfeld (1987) classification (see Hethey-Meier/Seth 2010: $32 \mathrm{ff}$.) and include the percentage shares of several higher-skilled occupational groups in an establishment's workforce. As further controls we include the percentages of females and of low-qualified employees, i.e. those, who do not have either an upper secondary school leaving certificate as their highest school qualification or a vocational qualification. To take account of aggregate business cycle fluctuations and other time-dependent effects, we use 21 year dummies. Since regional economic conditions generally seem to have a considerable impact on establishment exits (see e.g. Buehler et al. 2010), local labor market conditions are taken into account by using unemployment rates for 326 administrative districts in West Germany. As these regional unemployment data are only available from 1985 onwards, we have to restrict our multivariate analysis to the period 1985 to 2006 . Summary statistics of all explanatory variables are listed in an appendix table.

Estimation results for the period 1985 to 2006 are presented in Table 1. The first column (model 1 ) shows the results of a general analysis of the determinants of exit that does not take into account that these may differ between young and mature establishments. This issue is considered in model 2 where all explanatory variables described above are interacted with a dummy variable which is one if an establishment is maximum five years old, and zero otherwise. Thus the second column of Table 1 presents the marginal effects for mature establishments (older than five years) while the coefficients of the interaction terms in the last column indicate to what extent these effects are different for young establishments.

(Table 1 about here)

Starting with the effects of size and age, it is visible that the results from the descriptive analysis are confirmed by the multivariate analysis. In model 1 , the probability of exit is 5.1 percentage points higher, ceteris paribus, for establishments which are not more than five years old, confirming the liability of newness. The fully interacted model 2 makes clear that the effect of age does not only show up in the coefficient of the age dummy but also influences the effects of all other covariates (which will be discussed in detail below). The coefficients of the size dummies in model 1 clearly confirm the liability of smallness. Like in the descriptive analysis, establishments with 1-3 employees face by far the highest mortality risk. Their 
probability of exit is 9.4 percentage points higher than that of establishments in the reference category of 20-49 employees. As we are not able to distinguish between true and spurious exits in the size class of 1-3 employees, this result should not be over-interpreted, but a clear negative (and statistically significant) relationship between size and mortality risk is also visible for the other size classes where we do not have this problem. The effects of establishment size in model 2 show a similar picture. The probability of exit is once again by far highest for establishments with 1-3 employees, and the liability of smallness exists for both young and mature establishments. The coefficients of the interaction terms in the right column clearly show that the impact of size is substantially stronger for young establishments. While for mature establishments with 1-3 employees the probability of exit is 8.2 percentage points higher than for mature establishments with 20-49 employees, for young establishments this difference is 4.1 percentage points higher. These results indicate that the disadvantages faced by small establishments are even more severe if a small establishment is also young.

Our estimation results also show a relationship between industry affiliation and the probability of exit, which is particularly pronounced for younger establishments. Contrasting the effects of industry affiliation for young and mature establishments, it can be seen that these effects are quite small for mature establishments but substantially higher for young establishments. The highest probability of exit can be observed for the service sector, where it is on average about 1.8 percentage points higher than in the manufacturing sector. For establishments that are older than five years the effect is quite small with about 0.25 percentage points while it is more than 4 percentage points higher for young establishments.

In line with other studies (e.g. Abowd et al. 2009, Geroski et al. 2010) we find that establishments with a higher qualified workforce are less likely to exit, i.e. higher percentages of skilled occupations and a lower percentage of low-skilled employees are associated with a lower probability of exit. Once again these effects are more pronounced for young establishments, indicating that hiring decisions play a substantial role for the survival of young establishments. We also find that establishments with a higher percentage of females in the workforce are less likely to exit, which again is more pronounced for young establishments. This is generally consistent with the results by Weber/Zulehner (2009) who find for Austria that firms 
with a low share of females relative to industry average face higher mortality risks. It supports the view that - if discrimination is costly - discriminatory employers may be more likely to exit due to lower profitability. Our findings are also in line with the result by Weber/Zulehner (2010) that entrants with females among their first hires have a higher probability of survival. They conclude that gender diversity is crucial for the success of start-ups who are particularly sensitive to hiring decisions.

As expected, the regional unemployment rate has a significant positive effect on the probability of exit, which is once again stronger for young establishments. This shows that regional economic conditions play an important role concerning establishments' mortality risks and that young establishments are more vulnerable to economic conditions, which is in line with the results of previous empirical studies outlined in section 3 . The fact that young establishments are more strongly affected by regional unemployment may also reflect that new firms are more often founded by previously unemployed workers in regions where unemployment is high and are therefore less successful (Buehler et al. 2010). ${ }^{10}$

The estimation coefficients of the yearly dummies in the multivariate analysis confirm that the probability of exit has increased over time, as could already be seen in the descriptive analysis. The fact that this time trend is still visible when other determinants of exit like size or industry affiliation are controlled for indicates that the rising mortality risk cannot be simply due to structural changes in the economy. Contrasting the coefficients of the yearly dummies for young and mature establishments shows that - with the exception of the second half of the 1980s - this increase in the exit probability was generally more pronounced for young establishments. In contrast to the pronounced upward trend, the estimated coefficients show few variations that can clearly be related to cyclical movements, in such a way confirming the finding by Boeri/Bellmann (1995) that exit (of new establishments) is not responsive to the business cycle.

Up to now we have seen that being a young firm makes a big difference in various respects. To examine the exact age dependence of establishment exits more

\footnotetext{
${ }^{10}$ As current unemployment may depend on the number of establishment exits and might therefore be endogenous, we also used the regional unemployment rate of the previous year instead of the current regional unemployment rate, which did not alter our results.
} 
carefully, taking into account that it may not simply decrease with age monotonically, we now estimate a linear probability model with one dummy for each age. This is done for the years 2001-2006 because we have more accurate information on age in the late exit cohorts: if an establishment was founded after 1975, we know its exact age, and if it already existed in 1975 and still exists in 2001, we can definitely state that it is older than 25 years. Establishments that are older than 25 years constitute the reference group in our estimation, the results of which are presented in Table 2. Additionally the age dependence of establishment exits is illustrated graphically in Figure 5 which shows the coefficients of the age dummies.

\section{(Table 2 about here)}

\section{(Figure 5 about here)}

In accordance with the liability of newness, we find that exit rates are very high initially. In the first year of existence an establishment's probability of exit is about twelve percentage points higher than that of establishments which are older than 25 years. During the following years the probability of exit decreases steeply. Hence a liability of adolescence cannot be observed with our annual data (which does not necessarily mean that it does not exist as the peak associated with the liability of adolescence may arise within the first year of existence). For establishments which are six years old, the mortality risk does not differ significantly from that of establishments which are older than 25 years, but from the seventh year on the probability of exit is significantly lower. The lowest probability of exit can be observed for establishments that are about 15-18 year old, where the probability of exit is about 1.3 to 1.4 percentage points lower than for the reference group. For higher ages, the exit probability rises steadily compared to this minimum. This clearly indicates that there is also a liability of aging but we cannot distinguish whether it is a liability of obsolescence or senescence. The effects of the other covariates in this model are generally similar to those in model 1 .

Note that these insights still hold when we perform a number of robustness checks such as making use of alternative estimation methods, applying other classifications of entries and exits, using alternative definitions of young establishments, or including the agricultural and mining sectors in our sample. We also re-ran our estimations with an inflow sample of establishments founded in 1976 or later for which we have exact 
information on age for all establishments. In order to make sure that establishments which survive in a certain year but exit shortly afterwards do not bias our estimation results, we further restricted the control group in our sample to establishments that continue to exist for at least three or five years. The results of these robustness checks are available on request.

While we have found empirical evidence for the existence of liabilities of aging, of newness and of smallness, some caveats are in order. It could be argued that establishment size is potentially endogenous since firms in economic distress may adjust employment already some time before they exit. Although this aspect has not received much attention in the literature yet, there are some studies confirming this hypothesis. Almus (2004) finds for new firms in Germany that they tend to shrink before they exit and that employment growth is smaller for dying firms compared to their surviving counterparts up to three years before closure. Bellone et al. (2006) obtain similar results for mature French manufacturing firms. Like establishment size, the structure of the workforce could also be endogenous. This is mainly because certain groups of employees, namely those with better labor market opportunities, may leave an establishment due to economic distress already before closure. Another potential reason is that the management of a distressed firm may try to dismiss less skilled workers first. The few empirical studies on this issue suggest that the structure of the workforce becomes less skilled before closure. Schwerdt (2011) finds for Austria that workers leaving dying firms already before closure are associated with better post-separation outcomes than those staying until the end. For the US, Lengermann/Vilhuber (2002) report that high-skilled workers are more likely to leave distressed firms. These considerations suggest that our (and other authors') results concerning the relationship between establishment size or workforce structure and the probability of exit should be taken with a pinch of salt, leaving room for further research. 


\section{Conclusion}

Using comprehensive data from a random sample of 50 percent of all establishments in West Germany over the period 1975 to 2006, this paper has investigated the probability of establishment exit and its determinants. We find that over our period of observation the average exit rate has risen by more than three percentage points. In order to test various "liabilities" of establishment survival identified in the theoretical and empirical literature, we have analyzed the impact of establishment size and put a special focus on differences between young and mature establishments. Our empirical analysis clearly shows that the mortality risk falls with establishment size, in such a way confirming the liability of smallness. The probability of exit is substantially higher for young establishments which are not more than five years old, thus confirming the liability of newness. A more detailed analysis of the age dependence of establishment exits reveals that exit rates first decline over time, reaching a minimum at ages 15 to 18 , and then rise again somewhat, suggesting that there also exists a liability of aging.

Interestingly, it is not only the mortality risk but also the impact of its determinants that differs significantly between young establishments (of maximum five years old) and older establishments. For young establishments, the negative impact of small size is substantially stronger, the composition of the workforce (in particular the shares of high-skilled and female employees) plays a more important role, the high risk of failure in the service sector is even higher, and the regional unemployment rate has a more pronounced positive effect on the probability of exit. In addition, the increase in the exit probability has been more pronounced for young establishments. This suggests that young establishments are more vulnerable in a number of ways.

The fact that young establishments face several disadvantages compared to their older counterparts implies that economic policy should aim at providing them equal opportunities in realizing promising business ideas. A recent study analyzing the failure of young (but not older) firms conducted by Egeln et al. (2010) on behalf of the Federal Ministry of Economics and Technology in Germany finds that even potentially successful young firms often have to exit due to a lack of financial resources, especially when combined with external shocks or typical beginner's mistakes which do not necessarily reflect a lack of competence. Possible options for political action 
proposed in this study are, inter alia, improving the access to financial resources for young firms and providing better opportunities for the continuation of promising businesses in case of insolvency. While this sounds sensible and would be supported by us, the survival of establishments cannot be an end in itself - other factors such as their extent of job creation and destruction or the quality of jobs provided should also be taken into account before taking political action. Policymakers should keep in mind that a policy which aims at completely avoiding establishment exits would not make much sense and will not be successful. Exits may be unwelcome from a political point of view, but in an economic perspective they are important vehicles of resource (re-)allocation, innovation and development. 


\section{References}

Abowd, J. M./McKinney, K. L./Vilhuber, L. (2009): The Link between Human Capital, Mass Layoffs and Firm Deaths, in: Dunne, T./Jensen, J. B./Roberts, M. J.(eds.): Producer Dynamics - New Evidence from Micro Data, Chicago/London, 447-472.

Addison, J. T./Bellmann, L./Kölling, A. (2004): Work Councils and Plant Closings in Germany, in: British Journal of Industrial Relations 42, 125-148.

Ai, C./Norton, E. C. (2003): Interaction terms in logit and probit models, in: Economics Letters 80, 123-129.

Aldrich, H. E./Auster, E. (1986): Even Dwarfs Started Small: Liabilities of Size and Age and their Strategic Implications, in: Research in Organizational Behavior 8, 165198.

Almus, M. (2004): The Shadow of Death - An Empirical Analysis of the Pre-Exit Performance of New German Firms, in: Small Business Economics 23, 189-201.

Audretsch, D. B. (1995): Innovation and Industry Evolution, Cambridge.

Audretsch, D. B./Mahmood, T. (1994): The Rate of Hazard Confronting New Firms and Plants in U.S. Manufacturing, in: Review of Industrial Organization 9, 41-56.

Audretsch, D. B./Santarelli E./Vivarelli, M. (1999): Start-up size and industrial dynamics: some evidence from Italian manufacturing, in: International Journal of Industrial Organization 17, 965-983.

Barron, D. N./West, E./Hannan, M. T. (1994): A Time to Grow and a Time to Die: Growth and Mortality of Credit Unions in New York City, 1914-1990, in: American Journal of Sociology 100, 381-421.

Bartelsman, E./Scarpetta, S./Schivardi, S. (2005): Comparative analysis of firm demographics and survival: evidence from micro-level sources in OECD countries, in: Industrial and Corporate Change 14, 365-391.

Baum, J. A. C./Amburgey, T. L. (2005): Organizational Ecology, in: Baum, J. A. C. (eds.): The Blackwell Companion to Organizations, Oxford, 304-326. 
Bellone, F./Musso, P./Quéré, M./Nesta, L. (2006): Productivity and market selection of French manufacturing firms in the nineties, in: Revue de L'OFCE 97, 319-349.

Bellone, F./Musso, P./Nesta, L./Quéré, M. (2008): Market selection along the firm life cycle, in: Industrial and Corporate Change 17, 753-777.

Bernard, A. B./Jensen, J. B. (2007): Firm structure, multinationals, and manufacturing plant deaths, in: Review of Economics and Statistics 89, 193-204.

Blossfeld, H.-P. (1987): Labor Market Entry and the Sexual Segregation of Careers in the Federal Republic of Germany, in: American Journal of Sociology 93, 89-118.

Boeri, T./Bellmann, L. (1995): Post-entry behavior and the cycle: Evidence from Germany, in: International Journal of Industrial Organization 13, 483-500.

Box, M. (2008): The death of firms: exploring the effects of environment and birth cohort on firm survival in Sweden, in: Small Business Economics 31, 379-393.

Brixy, U./Fritsch, M. (2002): Die Betriebsdatei der Beschäftigtenstatistik der Bundesanstalt für Arbeit, in: Fritsch, M./Grotz, R. (eds.): Das Gründungsgeschehen in Deutschland, Heidelberg, 55-78.

Brixy, U./Kohaut, S./Schnabel, C. (2006): How fast do newly founded firms mature? Empirical analyses on job quality in start-ups, in: Fritsch, M./Schmude, J. (eds.): Entrepreneurship in the Region, New York, 95-112.

Brüderl, J./Schüssler, R. (1990): Organizational Mortality: The Liabilities of Newness and Adolescence, in: Administrative Science Quarterly 35, 530-547.

Buehler, S./Kaiser, C./Jaeger, F. (2010): The geographic determinants of bankruptcy: evidence from Switzerland, in: Small Business Economics, published online 24 October 2010.

Cafferata, R./Abatecola, G./Poggesi, S. (2009): Revisiting Stinchcombe's 'liability of newness': a systematic literature review, in: International Journal of Globalization and Small Business 3, 374-392.

Carlton, D. W./Perloff, J. M. (2005): Modern Industrial Organization, $4^{\text {th }}$ edition, Boston et al. 
Carreira, C./Silva, F. (2010): No deep pockets: some stylized empirical results on firms' financial constraints, in: Journal of Economic Surveys 24, 731-753.

Carrol, G. R. (1983): A Stochastic Model of Organizational Mortality: Review and Reanalysis, in: Social Science Research 12, 303-329.

Carroll, G. R./Hannan, M. T. (2000): The Demography of Corporations and Industries, Princeton, New Jersey.

Caves, R. (1998): Industrial Organization and New Findings on the Turnover and Mobility of Firms, in: Journal of Economic Literature 36, 1947-1982.

Disney, R./Haskel, J./Heden, Y. (2003): Entry, Exit and Establishment Survival in UK Manufacturing, in: Journal of Industrial Economics 51, 91-112.

Dunne, T/Roberts, M. J./Samuelson, L. (1989): The Growth and Failure of U. S. Manufacturing Plants, in: Quarterly Journal of Economics, 671-698.

Eberle, J./Jacobebbinghaus, P./Ludsteck, J./Witter, J. (2011): Generation of timeconsistent industry codes in the face of classification changes - Simple heuristic based on the Establishment History Panel (BHP), FDZ-Methodenreport 5/2011, Nürnberg.

Egeln, J./Falk, U./Heger, D./Höwer, D./Metzger, G. (2010): Ursachen für das Scheitern junger Unternehmen in den ersten fünf Jahren ihres Bestehens, Studie im Auftrag des Bundesministeriums für Wirtschaft und Technologie, Mannheim/Neuss.

Ericson, R./Pakes, A. (1995): Markov-Perfect Industry Dynamics: A Framework forEmpirical Work, in: Review of Economic Studies 62, 53-82.

Esteve-Pérez, S./Manez-Castillejo, J. A. (2008): The Resource-Based Theory of the Firm and Firm Survival, in: Small Business Economics 30, 231-249.

Fichman, M./Levinthal, D. A. (1991): Honeymoons and the Liability of Adolescence: A New Perspective on Duration Dependence in Social and Organizational Relationships, in: Academy of Management Review 16, 442-468.

Freeman, J./Carrol, G. R./Hannan, M. T. (1983): The Liability of Newness: Age Dependence in Organizational Death Rates, in: American Sociological Review 48, 692-710. 
Geroski, P. A. (1995): What do we know about entry?, in: International Journal of Industrial Organization 13, 421-440.

Geroski, P. A./Mata, J./Portugal, P. (2010): Founding conditions and the survival of new firms, in: Strategic Management Journal 31, 510-529.

Hannan, M. T./Carrol, G. R./Dobrev, S. D./Han, J. (1998): Organizational Mortality in European and American Automobile Industries. Part I: Revisiting the Effects of Age and Size, in: European Sociological Review 14, 279-302.

Hannan, M. T./Freeman, J. (1984): Structural Inertia and Organizational Change, in: American Sociological Review 49, 149-164.

Harhoff, D./Stahl, K./Woywode, M. (1998): Legal form, growth and exit of west German firms - empirical results for manufacturing, construction, trade and service industries, in: Journal of Industrial Economics 96, 453-488.

Heckmann, M./Schnabel, C. (2006): Überleben und Beschäftigungsentwicklung neu gegründeter Betriebe, in: Bellmann, L./Wagner, J. (eds.): Betriebsdemographie, Beiträge zur Arbeitsmarkt- und Berufsforschung 305, Nürnberg, 1-29.

Hethey, T./Schmieder, J. F. (2010): Using Worker Flows in the Analysis of Establishment Turnover - Evidence from German Administrative Data, FDZMethodenreport 6/2010, Nürnberg.

Hethey-Meier, T./Seth, S. (2010): The Establishment History Panel (BHP) 1975 2008 - Handbook Version 1.0.2, FDZ-Datenreport 4/2010, Nürnberg.

Hopenhayn, H. A. (1992): Entry, Exit and Firm Dynamics in Long Run Equilibrium, in: Econometrica 60, 1127-1150.

Jenkins, S. P. (1995): Easy ways to estimate discrete time duration models, in: Oxford Bulletin of Economics and Statistics 57, 129-138.

Jenkins, S. P. (2005): Survival Analysis, unpublished manuscript, Institute for Social and Economic Research, University of Essex, Colchester.

Jensen, P. H./Webster, E./Buddelmeyer, H. (2008): Innovation, Technological Conditions and New Firm Survival, in: Economic Record 84, 434-448. 
Jovanovic, B. (1982): Selection and the Evolution of Industry, in: Econometrica 50, 649-670.

Lengermann, P./Vilhuber, L. (2002): Abandoning the Sinking Ship: The Composition of Worker Flows Prior to Displacement, LEHD Technical Paper No. TP-2002-11, Suitland, Maryland.

Lucas, R. E. (1978): On the Size Distribution of Business Firms, in: Bell Journal of Economics 9, 508-523.

Mata, J. (1996): Markets, entrepreneurs and the size of new firms, in: Economics Letters 52, 89-94.

Mata, J./Portugal, P./Guimeraes, P. (1995): The survival of new plants: Start-up conditions and post-entry evolution, in: International Journal of Industrial Organization 13, 459-481.

Niese, M. (2003): Ursachen von Betriebsschließungen, Münster.

Ouyang, M. (2009): The scarring effect of recessions, in: Journal of Monetary Economics 56, 184-199.

Ranger-Moore, J. (1997): Bigger May be Better, But is Older Wiser? Organizational Age and Size in the New York Life Insurance Industry, in: American Sociological Review 62, 903-920.

Schindele, Y./Weyh, A. (2011): The direct employment effects of new businesses in Germany revisited: an empirical investigation for 1976-2004, in: Small Business Economics 36, 353-363.

Schwerdt, G. (2011): Labor turnover before plant closure: "Leaving the sinking ship" vs. "Captain throwing ballast overboard", in: Labour Economics 18: 93-101.

Spengler, A. (2008): The Establishment History Panel, in: Schmollers Jahrbuch 128, 501-509.

Stinchcombe, A. (1965): Social Structure and Organizations, in: March, J. G. (Hrsg.): Handbook of Organizations, Chicago, 142-193. 
Strotmann, H. (2007): Entrepreneurial Survival, in: Small Business Economics 28, 87-104.

Thornhill, S./Amit, R. (2003): Learning about Failure: Bankruptcy, Firm Age, and the Resource-Based View, in: Organization Science 14, 497-509.

Wagner, J. (1994): The post-entry performance of new firms in German manufacturing industries, in: Journal of Industrial Economics 92, 141-154.

Wagner, J. (1999): The Life History of Cohorts of Exits from German Manufacturing, in: Small Business Economics 13, 71-79.

Wagner, J. (2006): Firmenalter und Firmenperformance: Empirische Befunde zu Unterschieden zwischen jungen und alten Firmen in Deutschland, in: Bellmann, L./Wagner, J. (eds.): Betriebsdemographie, Beiträge zur Arbeitsmarkt- und Berufsforschung 305, Nürnberg, 83-111.

Wagner, J. (2010): Entry, Exit and Productivity: Empirical Results for German Manufacturing Industries, in: German Economic Review 11, 78-85.

Weber, A./Zulehner, C. (2009): Competition and Gender Prejudice: Are Discriminatory Employers Doomed to Fail?, CESifo Working Paper 2842, Munich.

Weber, A./Zulehner, C. (2010): Female Hires and the Success of Start-up Firms, in: American Economic Review 100, 358-361.

Wooldridge, J. M. (2010): Econometric analysis of cross section and panel data, 2nd ed., Cambridge.

Woywode, M. (1998): Determinanten der Überlebenswahrscheinlichkeit von Unternehmen, Baden-Baden. 
Figure 1: Annual exit rates and unemployment rates 1975-2006

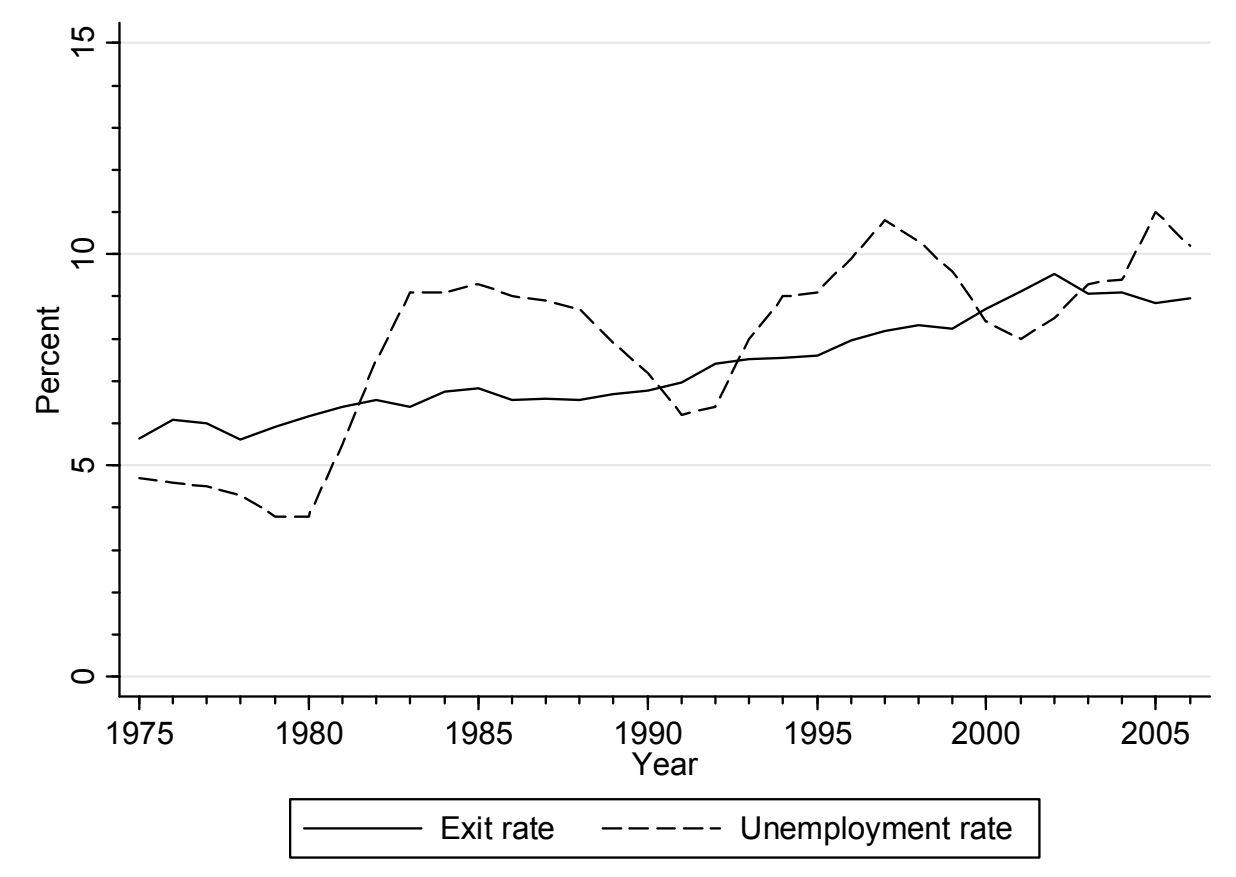

Notes: West Germany, all private sectors;

Figure 2: Average exit rates by economic activity 1975-2006

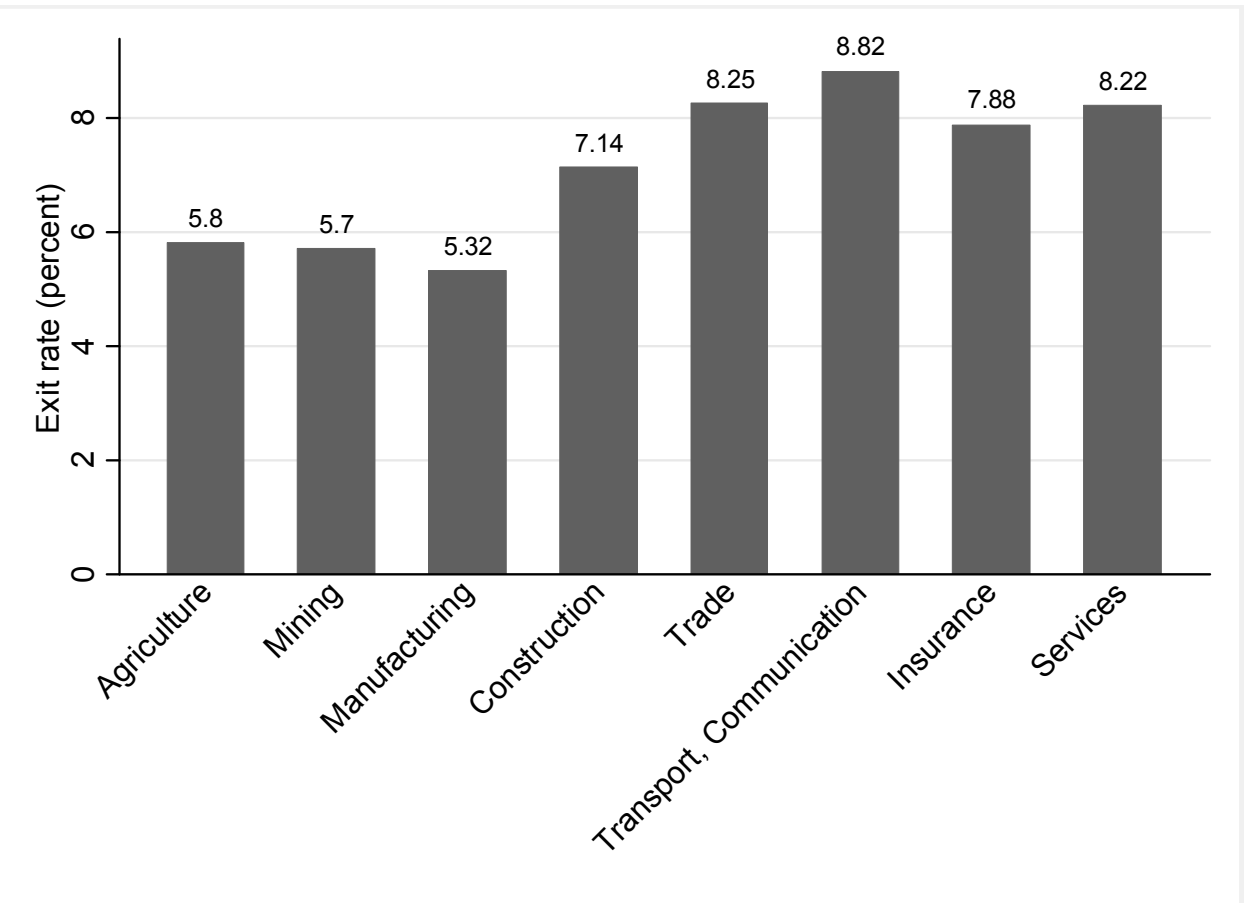

Notes: West Germany, private sector; 
Figure 3: Annual exit rates for different establishment size classes 1975-2006

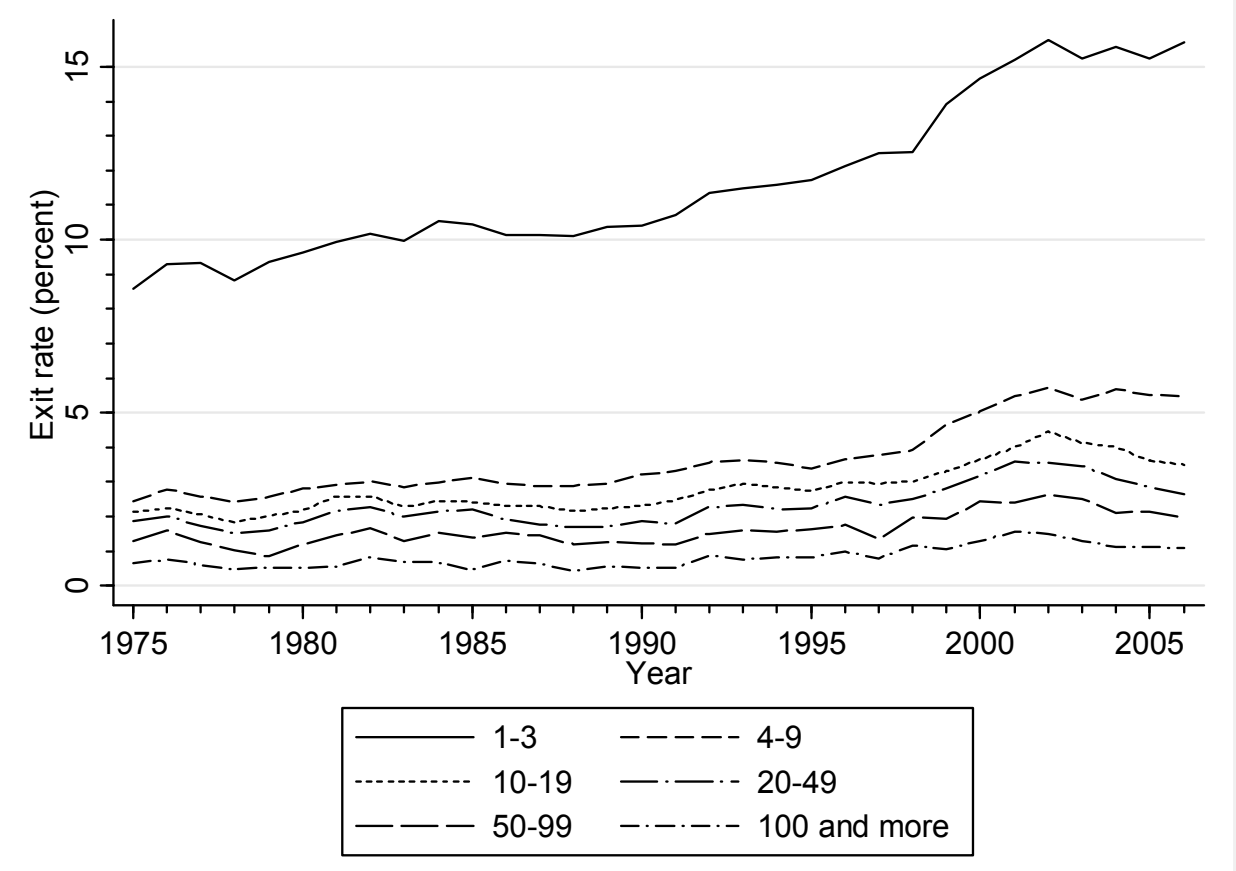

Notes: West Germany, private sector without agriculture and mining;

Figure 4: Annual exit rates for young and mature establishments 1981-2006

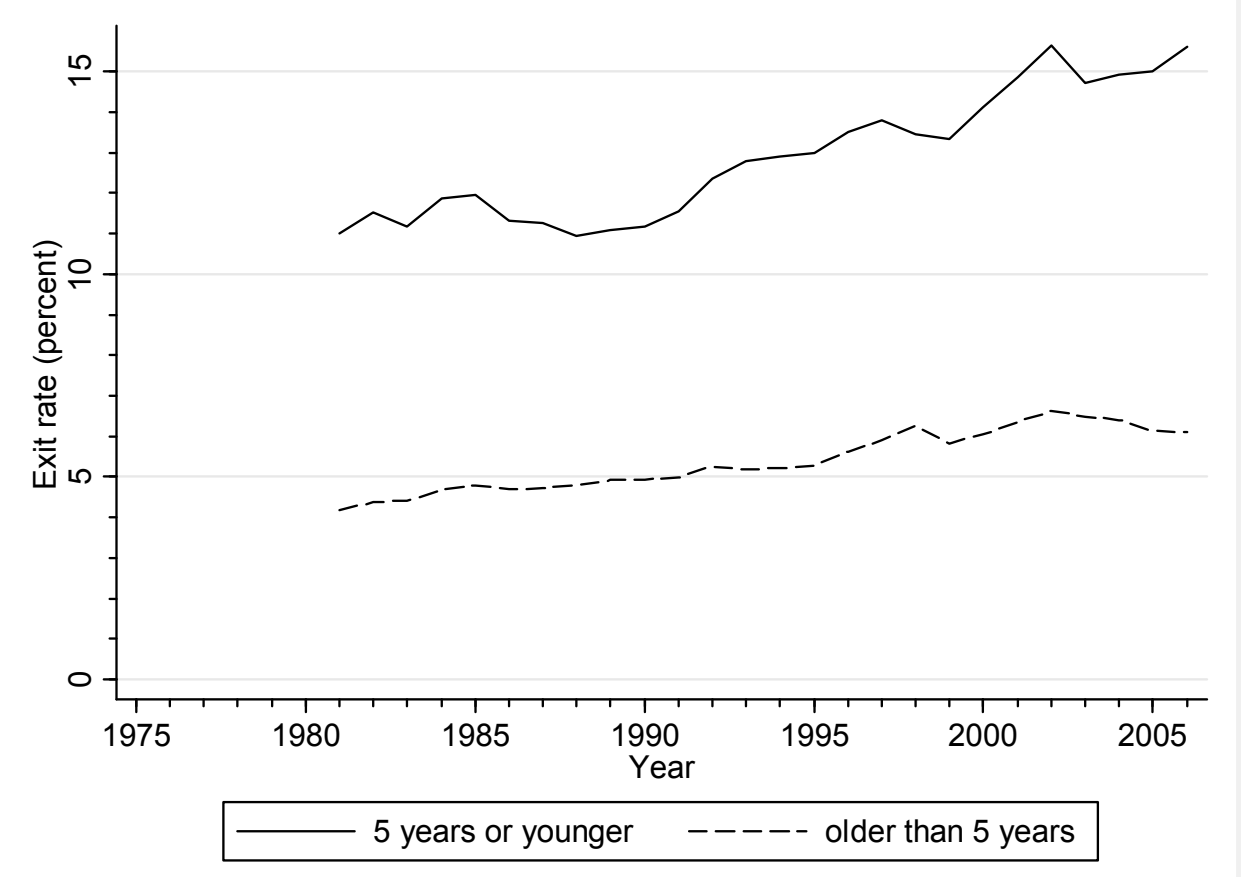

Notes: West Germany, private sector without agriculture and mining; 
Figure 5: Age dependence of establishment exits 2001-2006

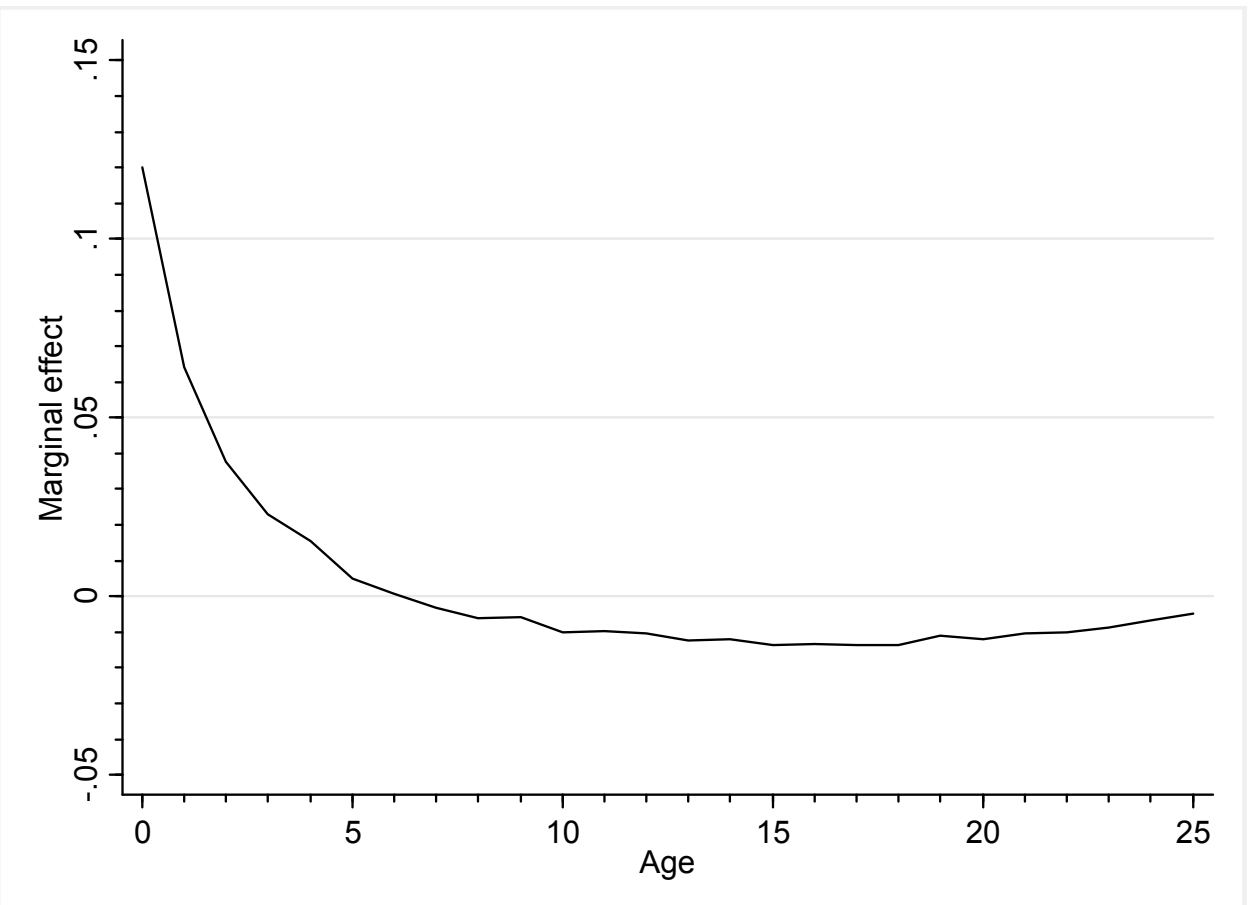

Notes: The graph shows coefficients of age-dummies obtained from a linear probability model (see Table 2); reference: establishments which are older than 25 years. 
Table 1: Determinants of establishment exits $(1=$ yes), 1985-2006, linear probability models

\begin{tabular}{|c|c|c|c|}
\hline & \multirow[t]{2}{*}{ Model 1} & \multicolumn{2}{|c|}{ Model 2} \\
\hline & & & $\begin{array}{l}\text { Interaction effect with } \\
\text { dummy for young } \\
\text { establishment }\end{array}$ \\
\hline Young establishment ( $\leq 5$ years; dummy) & $0.05115(129.80)^{* * *}$ & $0.01769(8.56)^{* * *}$ & --- \\
\hline 1-3 employees (dummy) & $0.09436(114.16)^{\star * *}$ & $0.08246(115.41)^{\star * *}$ & $0.04137(44.92)^{\star * *}$ \\
\hline 4-9 employees (dummy) & $0.02035(51.17)^{\star * *}$ & $0.01733(50.53)^{* * *}$ & $0.01431(17.14)^{* * *}$ \\
\hline 10-19 employees (dummy) & $0.00727(24.25)^{\star * *}$ & $0.00530(20.79)^{* * *}$ & $0.01133(11.78)^{* * *}$ \\
\hline 20-49 employees (reference) & --- & --- & 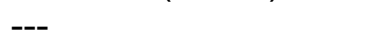 \\
\hline 50-99 employees (dummy) & $-0.00701(-19.65)^{\star * *}$ & $-0.00531(-15.98)^{* * *}$ & $-0.01953(-13.62)^{\star * *}$ \\
\hline 100-249 employees (dummy) & $-0.01068(-23.59)^{* * *}$ & $-0.00984(-29.78)^{* * *}$ & $-0.02768(-13.70)^{* * *}$ \\
\hline 250 and more employees (dummy) & $-0.01244(-23.37)^{* * *}$ & $-0.01439(-33.28)^{* * *}$ & $-0.03031(-10.78)^{* * *}$ \\
\hline Manufacturing (reference) & --- & --- & --- \\
\hline Construction (dummy) & $0.00999(17.91)^{* * *}$ & $0.00250(6.32)^{* * *}$ & $0.03029(16.64)^{* * *}$ \\
\hline Trade (dummy) & $0.00917(19.19)^{* * *}$ & $0.00382(8.52)^{* * *}$ & $0.02036(27.43)^{* * *}$ \\
\hline Transport, communication (dummy) & $0.00821(9.74)^{* * *}$ & $0.00259(3.93)^{* * *}$ & $0.02437(16.02)^{* * *}$ \\
\hline Insurance (dummy) & $-0.00176(-1.86)^{*}$ & $-0.00578(-5.94)^{* * *}$ & $0.01477(9.34)^{* * *}$ \\
\hline Services (dummy) & $0.01789(37.28)^{* * *}$ & $0.00251(6.17)^{\star \star *}$ & $0.04104(35.81)^{* * *}$ \\
\hline Percentage of female employees & $-0.00021(-35.65)^{\star * *}$ & $-0.00006(-11.44)^{\star * \star}$ & $-0.00030(-43.43)^{* * *}$ \\
\hline Percentage of low qualified employees & $0.00005(8.98)^{* * *}$ & $9.37 \mathrm{e}-06(1.93)^{*}$ & $0.00010(11.64)^{* * *}$ \\
\hline Percentage of skilled manual occupations & $-0.00029(-59.72)^{* * *}$ & $-0.00016(-42.70)^{* * *}$ & $-0.00028(-30.25)^{* * *}$ \\
\hline Percentage of skilled services & $-0.00060(-103.57)^{* * *}$ & $-0.00028(-61.97)^{\star \star *}$ & $-0.00087(-66.64)^{\star * *}$ \\
\hline Percentage of skilled commercial and administrative occupations & $-0.00027(-45.67)^{* * *}$ & $-0.00014(-24.86)^{* * *}$ & $-0.00030(-36.02)^{* * *}$ \\
\hline Percentage of technicians & $-0.00039(-55.67)^{* * *}$ & $-0.00014(-19.77)^{* * *}$ & $-0.00057(-41.80)^{* * *}$ \\
\hline Percentage of semiprofessions & $-0.00041(-36.68)^{* * *}$ & $-0.00016(-14.60)^{* * *}$ & $-0.00048(-24.37)^{* * *}$ \\
\hline Percentage of engineers & $-0.00038(-28.67)^{\star * *}$ & $-0.00007(-4.65)^{* * *}$ & $-0.00065(-28.48)^{* * *}$ \\
\hline Percentage of professions & $-0.00039(-25.11)^{* * *}$ & $-0.00020(-12.82)^{* * *}$ & $-0.00061(-18.04)^{* * *}$ \\
\hline Percentage of managers & $-0.00026(-22.39)^{* * *}$ & $-0.00011(-10.36)^{* * *}$ & $-0.00033(-23.31)^{* * *}$ \\
\hline
\end{tabular}




\begin{tabular}{|c|c|c|c|}
\hline Regional unemployment rate (percent) & $0.00222(18.66)^{* * *}$ & $0.00175(18.50)^{* * *}$ & $0.00135(10.77)^{\star \star *}$ \\
\hline Year 1985 (reference) & -- & -- & -- \\
\hline Year 1986 (dummy) & $-0.00112(-2.25)^{* *}$ & $0.00006(0.11)$ & $-0.00416(-3.77)^{* * *}$ \\
\hline Year 1987 (dummy) & $-0.00121(-2.18)^{\star *}$ & $0.00013(0.26)$ & $-0.00468(-4.11)^{* * *}$ \\
\hline Year 1988 (dummy) & $-0.00187(-3.14)^{* * *}$ & $0.00058(0.89)$ & $-0.00809(-6.37)^{* * *}$ \\
\hline Year 1989 (dummy) & $0.00399(5.78)^{* * *}$ & $0.00540(7.98)^{* * *}$ & $-0.00498(-4.15)^{\star * *}$ \\
\hline Year 1990 (dummy) & $0.00581(7.61)^{\star * *}$ & $0.00677(9.27)^{\star * *}$ & $-0.00361(-2.93)^{* * *}$ \\
\hline Year 1991 (dummy) & $0.00978(12.69)^{* * *}$ & $0.00914(11.98)^{* * *}$ & $0.00126(1.01)$ \\
\hline Year 1992 (dummy) & $0.01390(19.32)^{\star * *}$ & $0.01162(16.37)^{* * *}$ & $0.00597(4.37)^{* * *}$ \\
\hline Year 1993 (dummy) & $0.01147(22.36)^{\star * *}$ & $0.00821(13.83)^{* * *}$ & $0.00877(6.29)^{* * *}$ \\
\hline Year 1994 (dummy) & $0.00943(16.84)^{* * *}$ & $0.00649(12.24)^{* * *}$ & $0.00781(5.63)^{* * *}$ \\
\hline Year 1995 (dummy) & $0.00982(17.32)^{* * *}$ & $0.00684(11.88)^{* * *}$ & $0.00750(5.74)^{\star * *}$ \\
\hline Year 1996 (dummy) & $0.01172(21.01)^{* * *}$ & $0.00859(14.48)^{* * *}$ & $0.00781(5.69)^{* * *}$ \\
\hline Year 1997 (dummy) & $0.01203(19.56)^{* * *}$ & $0.00941(15.56)^{* * *}$ & $0.00616(4.98)^{\star * *}$ \\
\hline Year 1998 (dummy) & $0.01429(23.70)^{\star * *}$ & $0.01361(22.57)^{* * *}$ & $-0.00004(-0.03)$ \\
\hline Year 1999 (dummy) & $0.02092(34.76)^{* * *}$ & $0.01827(29.46)^{* * *}$ & $0.00659(4.94)^{* * *}$ \\
\hline Year 2000 (dummy) & $0.02829(45.48)^{* * *}$ & $0.02319(36.09)^{* * *}$ & $0.01341(9.74)^{* * *}$ \\
\hline Year 2001 (dummy) & $0.03371(59.31)^{* * *}$ & $0.02673(45.17)^{* * *}$ & $0.01888(14.71)^{* * *}$ \\
\hline Year 2002 (dummy) & $0.03660(60.86)^{* * *}$ & $0.02824(45.22)^{* * *}$ & $0.02292(16.52)^{* * *}$ \\
\hline Year 2003 (dummy) & $0.03093(49.92)^{* * *}$ & $0.02562(44.87)^{* * *}$ & $0.01441(10.24)^{* * *}$ \\
\hline Year 2004 (dummy) & $0.03209(51.74)^{* * *}$ & $0.02568(42.03)^{\star * *}$ & $0.01772(11.59)^{* * *}$ \\
\hline Year 2005 (dummy) & $0.02629(41.59)^{* * *}$ & $0.01963(33.04)^{* * *}$ & $0.01895(14.18)^{* * *}$ \\
\hline Year 2006 (dummy) & $0.03004(48.58)^{* * *}$ & $0.02099(34.97)^{* * *}$ & $0.02655(19.29)^{* * *}$ \\
\hline Intercept & $-0.00330(-2.32)^{* *}$ & $-0.00098(-0.84)$ & \\
\hline R-squared & 0.0433 & 0.0466 & \\
\hline
\end{tabular}

Notes: West Germany, private sector without agriculture and mining; t-values in brackets, standard errors adjusted for cluster on district level,

$* * * / * * / *$ indicates statistical significance at $1 / 5 / 10 \%$ level. 
Table 2: Determinants of establishment exits $(1=$ yes $)$ when specifically controlling for age, 2001-2006, linear probability model

\begin{tabular}{|c|c|}
\hline & Model 3 \\
\hline Age 0 (dummy) & $0.11993(109.60)^{* * *}$ \\
\hline Age 1 (dummy) & $0.06414(64.39)^{\star * *}$ \\
\hline Age 2 (dummy) & $0.03782(41.59)^{* * *}$ \\
\hline Age 3 (dummy) & $0.02295(25.68)^{* * *}$ \\
\hline Age 4 (dummy) & $0.01544(16.69)^{* * *}$ \\
\hline Age 5 (dummy) & $0.00513(6.28)^{* * *}$ \\
\hline Age 6 (dummy) & $0.00088(1.19)$ \\
\hline Age 7 (dummy) & $-0.00325(-3.96)^{\star * *}$ \\
\hline Age 8 (dummy) & $-0.00603(-7.92)^{* * *}$ \\
\hline Age 9 (dummy) & $-0.00583(-6.68)^{* * *}$ \\
\hline Age 10 (dummy) & $-0.01001(-11.11)^{\star * *}$ \\
\hline Age 11 (dummy) & $-0.00981(-10.97)^{* * *}$ \\
\hline Age 12 (dummy) & $-0.01043(-11.30)^{* * *}$ \\
\hline Age 13 (dummy) & $-0.01243(-14.19)^{* * *}$ \\
\hline Age 14 (dummy) & $-0.01216(-13.10)^{* * *}$ \\
\hline Age 15 (dummy) & $-0.01357(-15.24)^{\star * *}$ \\
\hline Age 16 (dummy) & $-0.01335(-14.30)^{\star * *}$ \\
\hline Age 17 (dummy) & $-0.01362(-15.34)^{\star * *}$ \\
\hline Age 18 (dummy) & $-0.01353(-12.58)^{\star * *}$ \\
\hline Age 19 (dummy) & $-0.01114(-11.05)^{\star * *}$ \\
\hline Age 20 (dummy) & $-0.01186(-11.66)^{\star * *}$ \\
\hline Age 21 (dummy) & $-0.01031(-9.82)^{* * *}$ \\
\hline Age 22 (dummy) & $-0.01019(-9.50)^{\star * *}$ \\
\hline Age 23 (dummy) & $-0.00865(-7.58)^{\star * *}$ \\
\hline Age 24 (dummy) & $-0.00664(-5.71)^{\star * *}$ \\
\hline Age 25 (dummy) & $-0.00474(-4.21)^{\star * *}$ \\
\hline Age $>25$ (reference) & -- \\
\hline 1-3 employees (dummy) & $0.10978(131.98)^{\star * *}$ \\
\hline 4-9 employees (dummy) & $0.02764(49.93)^{* * *}$ \\
\hline 10-19 employees (dummy) & $0.01060(22.37)^{\star * *}$ \\
\hline 20-49 employees (reference) & --- \\
\hline 50-99 employees (dummy) & $-0.00960(-14.20)^{\star * *}$ \\
\hline 100-249 employees (dummy) & $-0.01567(-21.70)^{\star * *}$ \\
\hline 250 and more employees (dummy) & $-0.01933(-21.95)^{\star * *}$ \\
\hline Manufacturing (reference) & --- \\
\hline Construction (dummy) & $0.01016(12.28)^{\star \star *}$ \\
\hline Trade (dummy) & $0.01505(23.95)^{\star * *}$ \\
\hline Transport, communication (dummy) & $0.01944(18.58)^{\star \star *}$ \\
\hline Insurance (dummy) & $0.00004(0.03)$ \\
\hline Services (dummy) & $0.02508(43.41)^{\star * *}$ \\
\hline Percentage of female employees & $-0.00023(-27.88)^{\star * *}$ \\
\hline Percentage of low qualified employees & $0.00007(7.29)^{\star * *}$ \\
\hline Percentage of skilled manual occupations & $-0.00026(-30.58)^{\star * *}$ \\
\hline Percentage of skilled services & $-0.00061(-76.78)^{\star * *}$ \\
\hline Percentage of skilled commercial and administrative occupations & $-0.00032(-38.90)^{* * *}$ \\
\hline Percentage of technicians & $-0.00036(-23.54)^{\star * *}$ \\
\hline Percentage of semiprofessions & $-0.00043(-25.63)^{* * *}$ \\
\hline Percentage of engineers & $-0.00039(-19.15)^{\star * *}$ \\
\hline Percentage of professions & $-0.00033(-12.38)^{\star * *}$ \\
\hline Percentage of managers & $-0.00032(-18.12)^{\star * *}$ \\
\hline Regional unemployment rate (percent) & $0.00233(20.86)^{* * *}$ \\
\hline
\end{tabular}




\begin{tabular}{l|l}
\hline Year 2001 (reference) & --- \\
Year 2002 (dummy) & $0.00348(6.95)^{* * *}$ \\
Year 2003 (dummy) & $-0.00159(-2.84)^{\star * *}$ \\
Year 2004 (dummy) & $-0.00044(-0.80)$ \\
Year 2005 (dummy) & $-0.00706(-10.35)^{\star * *}$ \\
Year 2006 (dummy) & $-0.00339(-10.35)^{* * *}$ \\
\hline Intercept & $0.01940(14.16)^{* * *}$ \\
\hline R-squared & 0.0580 \\
Number of observations & $3,702,033$ \\
\hline Notes: West Germany, private sector without agriculture and mining; t-values in brackets, \\
standard errors adjusted for cluster on district level, ${ }^{* * *} /{ }^{* *} / *$ \\
1/5/10\% level.
\end{tabular}


Appendix Table 1: Descriptive statistics (regression sample 1985-2006)

\begin{tabular}{|c|c|c|c|c|c|c|}
\hline & \multicolumn{2}{|c|}{ All observations } & \multicolumn{2}{|c|}{ Exits } & \multicolumn{2}{|c|}{ Survivors } \\
\hline & Mean & Std. Dev. & Mean & Std. Dev. & Mean & Std. Dev. \\
\hline Young establishment ( $\leq 5$ years; dummy) & 0.32990 & 0.47018 & 0.53865 & 0.49850 & 0.31147 & 0.46309 \\
\hline 1-3 employees (dummy) & 0.51383 & 0.49981 & 0.78553 & 0.41046 & 0.48984 & 0.49990 \\
\hline 4-9 employees (dummy) & 0.28939 & 0.45348 & 0.15044 & 0.35750 & 0.30165 & 0.45898 \\
\hline 10-19 employees (dummy) & 0.10288 & 0.30380 & 0.04018 & 0.19637 & 0.10842 & 0.31091 \\
\hline 20-49 employees (dummy) & 0.05827 & 0.23425 & 0.01802 & 0.13302 & 0.06182 & 0.24083 \\
\hline 50-99 employees (dummy) & 0.01922 & 0.13730 & 0.00404 & 0.06346 & 0.02056 & 0.14191 \\
\hline 100-249 employees (dummy) & 0.01111 & 0.10480 & 0.00150 & 0.03864 & 0.01196 & 0.10869 \\
\hline 250 and more employees (dummy) & 0.00530 & 0.07264 & 0.00030 & 0.01728 & 0.00575 & 0.07558 \\
\hline Manufacturing (dummy) & 0.20300 & 0.40224 & 0.14681 & 0.35392 & 0.20797 & 0.40585 \\
\hline Construction (dummy) & 0.10349 & 0.30460 & 0.10259 & 0.30343 & 0.10357 & 0.30470 \\
\hline Trade (dummy) & 0.25908 & 0.43813 & 0.28336 & 0.45063 & 0.25694 & 0.43694 \\
\hline Transport, communication (dummy) & 0.03845 & 0.19228 & 0.04648 & 0.21052 & 0.03774 & 0.19057 \\
\hline Insurance (dummy) & 0.01635 & 0.12681 & 0.01734 & 0.13052 & 0.01626 & 0.12648 \\
\hline Services (dummy) & 0.37963 & 0.48529 & 0.40342 & 0.49058 & 0.37753 & 0.48477 \\
\hline Percentage of female employees & 54.32365 & 40.09834 & 52.14148 & 44.58777 & 54.51621 & 39.67180 \\
\hline Percentage of low qualified employees & 16.70421 & 27.23143 & 15.72105 & 32.09646 & 16.79102 & 26.75769 \\
\hline Percentage of skilled manual occupations & 20.02414 & 33.68714 & 17.77467 & 34.66400 & 20.22275 & 33.59230 \\
\hline Percentage of skilled services & 12.14216 & 30.18379 & 7.83313 & 25.57566 & 12.52261 & 30.52807 \\
\hline Percentage of skilled commercial and administrative occupations & 21.04388 & 32.78958 & 21.92915 & 37.61616 & 20.96572 & 32.32767 \\
\hline Percentage of technicians & 3.43263 & 14.49039 & 2.83921 & 14.82376 & 3.48503 & 14.45942 \\
\hline Percentage of semiprofessions & 1.11437 & 8.95492 & 1.01896 & 9.26784 & 1.12280 & 8.92672 \\
\hline Percentage of engineers & 1.13789 & 8.09207 & 1.08706 & 9.20157 & 1.14238 & 7.98670 \\
\hline Percentage of professions & 0.75358 & 5.77471 & 0.53072 & 6.00331 & 0.77326 & 5.75368 \\
\hline Percentage of managers & 3.30646 & 14.27636 & 3.57858 & 16.60682 & 3.28243 & 14.05179 \\
\hline Regional unemployment rate (percent) & 8.52385 & 3.27247 & 8.82692 & 3.30963 & 8.49709 & 3.26782 \\
\hline Number of observations & \multicolumn{2}{|c|}{$13,088,949$} & \multicolumn{2}{|c|}{$1,061,889$} & \multicolumn{2}{|c|}{$12,027,060$} \\
\hline
\end{tabular}

Notes: West Germany, private sector without agriculture and mining 


\section{Working Paper Series in Economics}

(recent issues)

No.230: Institut für Volkswirtschaftslehre: Forschungsbericht 2011, January 2012

No.229: Frank Schmielewski: Leveraging and risk taking within the German banking system: Evidence from the financial crisis in 2007 and 2008, January 2012

No.228: Daniel Schmidt and Frank Schmielewski: Consumer reaction on tumbling funds Evidence from retail fund outflows during the financial crisis 2007/2008, January 2012

No.227: Joachim Wagner: New Methods for the Analysis of Links between International Firm Activities and Firm Performance: A Practitioner's Guide, January 2012

No.226: Alexander Vogel and Joachim Wagner: The Quality of the KombiFiD-Sample of Business Services Enterprises: Evidence from a Replication Study, January 2012

No.225: Stefanie Glotzbach: Environmental justice in agricultural systems. An evaluation of success factors and barriers by the example of the Philippine farmer network MASIPAG, January 2012

No.224: Joachim Wagner: Average wage, qualification of the workforce and export performance in German enterprises: Evidence from KombiFiD data, January 2012

No.223: Maria Olivares and Heike Wetzel: Competing in the Higher Education Market: Empirical Evidence for Economies of Scale and Scope in German Higher Education Institutions, December 2011

No.222: Maximilian Benner: How export-led growth can lead to take-off, December 2011

No.221: Joachim Wagner and John P. Weche Gelübcke: Foreign Ownership and Firm Survival: First evidence for enterprises in Germany, December 2011

No.220: Martin F. Quaas, Daan van Soest, and Stefan Baumgärtner: Complementarity, impatience, and the resilience of natural-resource-dependent economies, November 2011

No.219: Joachim Wagner: The German Manufacturing Sector is a Granular Economy, November 2011

No.218: Stefan Baumgärtner, Stefanie Glotzbach, Nikolai Hoberg, Martin F. Quaas, and Klara Stumpf: Trade-offs between justices, economics, and efficiency, November 2011

No.217: Joachim Wagner: The Quality of the KombiFiD-Sample of Enterprises from Manufacturing Industries: Evidence from a Replication Study, November 2011

No.216: John P. Weche Gelübcke: The Performance of Foreign Affiliates in German Manufacturing: Evidence from a new Database, November 2011

No.215: Joachim Wagner: Exports, Foreign Direct Investments and Productivity: Are services firms different?, September 2011

No.214: Stephan Humpert and Christian Pfeifer: Explaining Age and Gender Differences in Employment Rates: A Labor Supply Side Perspective, August 2011

No.213: John P. Weche Gelübcke: Foreign Ownership and Firm Performance in German Services: First Evidence based on Official Statistics, August 2011

[forthcoming in: The Service Industries Journal] 
No.212: John P. Weche Gelübcke: Ownership Patterns and Enterprise Groups in German Structural Business Statistics, August 2011 [published in: Schmollers Jahrbuch / Journal of Applied Social Science Studies, 131(2011), 4, 635-647]

No.211: Joachim Wagner: Exports, Imports and Firm Survival: First Evidence for manufacturing enterprises in Germany, August 2011

No.210: Joachim Wagner: International Trade and Firm Performance: A Survey of Empirical Studies since 2006, August 2011

No.209: Roland Olbrich, Martin F. Quaas, and Stefan Baumgärtner: Personal norms of sustainability and their impact on management - The case of rangeland management in semi-arid regions, August 2011

No.208: $\quad$ Roland Olbrich, Martin F. Quaas, Andreas Haensler and Stefan Baumgärtner: Risk preferences under heterogeneous environmental risk, August 2011

No.207: Alexander Vogel and Joachim Wagner: Robust estimates of exporter productivity premia in German business services enterprises, July 2011 [published in: Economic and Business Review, 13 (2011), 1-2, 7-26]

No.206: Joachim Wagner: Exports, imports and profitability: First evidence for manufacturing enterprises, June 2011

No.205: Sebastian Strunz: Is conceptual vagueness an asset? Resilience research from the perspective of philosophy of science, May 2011

No.204: Stefanie Glotzbach: On the notion of ecological justice, May 2011

No.203: Christian Pfeifer: The Heterogeneous Economic Consequences of Works Council Relations, April 2011

No.202: Christian Pfeifer, Simon Janssen, Philip Yang and Uschi Backes-Gellner: Effects of Training on Employee Suggestions and Promotions in an Internal Labor Market, April 2011

No.201: Christian Pfeifer: Physical Attractiveness, Employment, and Earnings, April 2011

No.200: Alexander Vogel: Enthüllungsrisiko beim Remote Access: Die Schwerpunkteigenschaft der Regressionsgerade, März 2011

No.199: Thomas Wein: Microeconomic Consequences of Exemptions from Value Added Taxation - The Case of Deutsche Post, February 2011

No.198: Nikolai Hoberg and Stefan Baumgärtner: Irreversibility, ignorance, and the intergenerational equity-efficiency trade-off, February 2011

No.197: Sebastian Schuetz: Determinants of Structured Finance Issuance - A Cross-Country Comparison, February 2011

No.196: Joachim Fünfgelt and Günther G. Schulze: Endogenous Environmental Policy when Pollution is Transboundary, February 2011

No.195: Toufic M. El Masri: Subadditivity and Contestability in the Postal Sector: Theory and Evidence, February 2011

No.194: Joachim Wagner: Productivity and International Firm Activities: What do we know?, January 2011 [published in: Nordic Economic Policy Review, 2011 (2), 137-161]

No.193: Martin F. Quaas and Stefan Baumgärtner: Optimal grazing management rules in semiarid rangelands with uncertain rainfall, January 2011

No.192: Institut für Volkswirtschaftslehre: Forschungsbericht 2010, Januar 2011 
No.191: Natalia Lukomska, Martin F. Quaas and Stefan Baumgärtner: Bush encroachment control and risk management in semi-arid rangelands, December 2010

No.190: Nils Braakmann: The causal relationship between education, health and health related behaviour: Evidence from a natural experiment in England, November 2010

No.189: Dirk Oberschachtsiek and Britta Ulrich: The link between career risk aversion and unemployment duration: Evidence of non-linear and time-depending pattern, October 2010

No.188: Joachim Wagner: Exports and Firm Characteristics in German Manufacturing industries, October 2010

No.187: Joachim Wagner: The post-entry performance of cohorts of export starters in German manufacturing industries, September 2010

No.186: Joachim Wagner: From estimation results to stylized facts: Twelve recommendations for empirical research in international activities of heterogenous firms, September 2010 [published in: De Economist, 159 (2011), 4, 389-412]

No.185: Franziska Dittmer and Markus Groth: Towards an agri-environment index for biodiversity conservation payment schemes, August 2010

No.184: Markus Groth: Die Relevanz von Ökobilanzen für die Umweltgesetzgebung am Beispiel der Verpackungsverordnung, August 2010

No.183: Yama Temouri, Alexander Vogel and Joachim Wagner: Self-Selection into Export Markets by Business Services Firms - Evidence from France, Germany and the United Kingdom, August 2010

No.182: David Powell and Joachim Wagner: The Exporter Productivity Premium along the Productivity Distribution: First Evidence from a Quantile Regression for Fixed Effects Panel Data Models, August 2010

No.181: Lena Koller, Claus Schnabel und Joachim Wagner: Beschäftigungswirkungen arbeitsund sozialrechtlicher Schwellenwerte , August 2010

[publiziert in: Zeitschrift für Arbeitsmarktforschung 44(2011), 1-2, 173-180]

No.180: Matthias Schröter, Markus Groth und Stefan Baumgärtner: Pigous Beitrag zur Nachhaltigkeitsökonomie, Juli 2010

No.179: Norbert Olah, Thomas Huth and Dirk Löhr: Monetary policy with an optimal interest structure, July 2010

No.178: Sebastian A. Schütz: Structured Finance Influence on Financial Market Stability Evaluation of Current Regulatory Developments, June 2010

No.177: Franziska Boneberg: The Economic Consequences of One-third Co-determination in German Supervisory Boards: First Evidence from the German Service Sector from a New Source of Enterprise Data, June 2010 [forthcoming in: Schmollers Jahrbuch / Journal of Applied Social Science Studies]

No.176: Nils Braakmann: A note on the causal link between education and health - Evidence from the German short school years, June 2010

No.175: Torben Zülsdorf, Ingrid Ott und Christian Papilloud: Nanotechnologie in Deutschland Eine Bestandsaufnahme aus Unternehmensperspektive, Juni 2010

No.174: Nils Braakmann: An empirical note on imitative obesity and a puzzling result, June 2010 


\section{Leuphana Universität Lüneburg}

Institut für Volkswirtschaftslehre

Postfach 2440

D-21314 Lüneburg

Tel.: ++49 41316772321

email: brodt@leuphana.de

www.leuphana.de/institute/ivwl/publikationen/working-papers.html 